Katja Mihurko Poniž Univerza v Novi Gorici Fakulteta za humanistiko Slovenija katja.mihurko.poniz@ung.si
DOI: https://doi.org/10.18485/slovenika.2019.5.1.1

UDK: 821.163.6.09:821.163.41.09

821.163.6.09 Кведер 3.

Znanstveni članek

\title{
Vezi Zofke Kveder s srbskim kulturnim prostorom ${ }^{1}$
}

Povzetek

$\checkmark$ članku so predstavljene različne oblike kulturnih stikov Zofke Kveder s srbskimi intelektualci in intelektualkami. V prvem delu članka so raziskane objave njenih literarnih besedil $v$ srbskem prostoru ter kritiški odzivi nanje. V drugem delu članka, izhajajoč iz korespondence Zofke Kveder, rekonstruiramo njen odnos s srbskim socialistom Dimitrijem Tucovićem, ki jo je navdušil za potovanje v Srbijo, kamor se je odpravila tik pred prvo svetovno vojno. To potovanje je $v$ nadaljevanju članka natančno opisano. Pozornost je usmerjena tudi na avtoričina dela, predvsem like Srbov in Srbkinj, ki se pojavljajo že v njenih zgodnjih literarnih besedilih. V romanu Hanka je v liku Kazimirja Staszyńskega upodobila moškega, ki ima veliko lastnosti Dimitrija Tucovića. Kot žena kraljevskega namestnika za Hrvaško in Slavonijo je Beograd po vojni večkrat obiskala in navezala številne stike, ki jih v nadaljevanju članka predstavljamo skozi pisateljičino korespondenco. Večina pisem, napisanih srbskim prijateljicam, je danes izgubljenih, a iz tistih, ki so ohranjena, si lahko ustvarimo podobo pisemskega omrežja Zofke Kveder na Balkanu in tudi razberemo, da so bile na srbskem prostoru z njo povezane predvsem avtorice in feministke. Sledijo še odzivi na delo in lik Zofke Kveder po njeni smrti - tako v nekrologih kot v literarnovednih študijah, ki so ji bile posvečene. Njeno delo je bilo sprejeto kot pomemben del južnoslovanske kulture in literature.

Ključne besede: Zofka Kveder, srbsko-slovenski literarni stiki, Dimitrije Tucović, Milica Đurić Topalović, Julka Chlapec Djordjević, Jelena J. Dimitrijević

\section{Uvod}

Zofka Kveder je bila že od mladih dni navdušena raziskovalka novih geografskih in kulturnih prostorov. Kot dvajsetletno dekle se je odpravila na študij v Švico, odvisna le od svojih prihrankov. Kasneje, spomladi leta 1900, se je za šest let ustalila v Pragi, ki je bila takrat

${ }^{1}$ Članek je rezultat dela na raziskovalnem programu »Historične interpretacije 20. stoletja« (P6-0347), ki ga financira Javna agencija za raziskovalno dejavnost Republike Slovenije iz državnega proračuna. 
središče mladih študentov s slovanskega juga. Stiki, ki jih je navezala $\checkmark$ češki prestolnici, so ji koristili ob selitvi $\vee$ Zagreb, a tudi kasneje, kot je razvidno iz njenih objav, saj je imela bogato korespondenčno mrežo. Njena želja po odkrivanju novih svetov in navezovanje stikov s predstavnicami in predstavniki tujih kultur so ji na začetku novega stoletja odprli vstop tudi v srbsko kulturno življenje. Njena prisotnost $v$ njem razkriva, da so potekale živahne in zanimive izmenjave, ki so obogatile obe strani: pisateljico in njeno publiko. Zato se bomo $v$ pričujočem članku posvetili različnim oblikam stikov Zofke Kveder. Najprej bomo predstavili, kako se je $v$ prvem desetletju novega stoletja srbskemu kulturnemu prostoru predstavila s svojimi literarnimi deli. $V$ drugem desetletju, predvsem v obdobju tik pred prvo svetovno vojno je Zofka Kveder sama spoznavala Srbijo in njeno kulturo, saj se je odpravila na potovanje, za katerega jo je navdušil srbski socialist Dimitrije Tucović. Njegov lik je v njej živel tudi, ko je na bojišču izgubil življenje. Takrat je iz prijatelja postal ideal moškega, ki ga je pisateljica prikazala v liku Kazimirja Staszyńskega v romanu Hanka (1917). Kot žena kraljevskega namestnika za Hrvaško in Slavonijo je Beograd po vojni večkrat obiskala in navezala številne stike, ki jih v nadaljevanju članka predstavljamo skozi pisateljičino korespondenco. Sledijo še odzivi na Zofko Kveder in njeno delo po njeni smrti - tako $v$ nekrologih kot $v$ literarnovednih študijah, ki so ji bile posvečene.

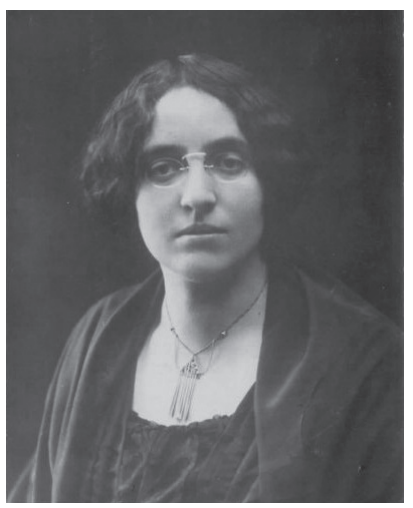

Slika 1 - Zofka Kveder, vir Wikipedija.

https://sl.wikipedia.org/wiki/Zofka_Kveder\#/media/Slika:Zofka_Kveder_1920s.jpg

\section{Liki Srbov v literarnem opusu Zofke Kveder}

$\checkmark$ pisateljičinih literarnih besedilih se kot osrednji liki pojavijo le Srbi, Srbkinj v njem ne najdemo. Protagonistki v novelah Gabrijela (1898) in Nekaj navadnega (1910) sta očarani nad lepoto, razgledanostjo in temperamentom moških likov, ki sta oba srbske narodnosti. Vendar se razmerje v obeh novelah nesrečno konča, saj sta moška lika preračunljiva in si želita le avanture s poročeno žensko, za katero ni- 
sta pripravljena tvegati svoje gmotne varnosti. Tudi tretje pisateljičino besedilo, kratka pripovedna proza Epizoda (1902), ki prikazuje ljubezensko nagnjenje med Slovenko in Srbom, se nesrečno konča, $v$ tem primeru zaradi pomanjkanja volje do življenja in odločnosti, kajti sodni pristav Dušan Jovanović je bolehni, blazirani človek, »njegovo držanje je bilo leno, nekako staro, $v$ lepem licu se je bralo dolgočasje in neka sitost vsega. Njegovo oko je bilo prazno, brez svita, ozke, vele roke so se nervozno poigravale s palčico« (Kveder 2005, 96). V odločilnem trenutku se Jovanović umakne, čeprav ga življenja polna Alma močno privlači in njuna ljubezen je le epizoda, ki je za dekle »kakor prva, huda slana« (Kveder 2005, 108).

Tudi v noveli Študentke (1900) se pojavi lik Srba, ki je zaljubljen $\checkmark$ eno od ženskih oseb, zapeljivo, a v ljubezni nesrečno Rusinjo Sašo Timofejevno. Pripovedovalka Popovića označi kot naivno dušo neprivlačne zunanjosti, a polnega empatije: »Mijo Popović jo je poslušal v zadregi. Prej jo je hotel prijeti za roko, samo da ji pove, da sočustvuje z njo, da kljub vsemu še čuti zanjo, da noče videti njene umazane preteklosti, a njene zadnje besede so mu vzele pogum in ves užaljen in zmešan se je poslovil. Bil je edini mož, ki mu Saša ni bila dražestna, a nizka, nevredna stvar ...« (Kveder 2010, 460).

Povsem drugače so Srbi prikazani v novelah, ki opisujejo balkanske vojne in so v hrvaščini izšle v zbirki Jedanaest novela (1913). V ospredju sta njihov pogum in možatost, a tudi premišljevanja o smislu vojne: »Prije ga nije nikada mučilo pitanje: Zašto? Sada je pak u njemu sve vrelo, kao da mu se otvaraju nova vrata, kao da mu se tek sada diže spoznanje da je čovjek - čovjek, koji misli, osjeća i pita, zašto ovo, zašto ono. $U$ ratu nikad nije promišljao, je li pravo ili nije, ako ispruži pušku. Naprotiv, ponosio se, što zna tako dobro gađati; i brojio je, pače, brojio, koliko je Turaka sravnio sa zemljom« (Kveder 1913, 115).

Kot ideal domoljubnega poguma sta v dramskem diptihu Unuk kraljeviča Marka (1922) predstavljena srbski podčasnik Marko Mrković in njegov narednik Mihajlo. Prva drama (Za svobodu) se dogaja leta 1914, eno izmed prizorišč je tudi trdnjava na Kalemegdanu, druga drama (Za ujedinjenje) kot eno izmed prizorišč postavlja kavarno Moskva v Beogradu. Drame, ki jih je Zofka Kveder pisala po prvi svetovni vojni, imajo le malo umetniških kvalitet, saj v njih prevladujejo tendenčne hvalnice novi državi, v kateri so njeni zagovorniki prikazani kot junaki, nasprotniki pa kot izdajalci (Badurina 2009, 183).

\section{Zofka Kveder v srbskem kulturnem prostoru v prvem desetletju novega stoletja}

Vstop Zofke Kveder v srbski kulturni prostor predstavljajo objave njenih besedil $v$ periodiki. Najverjetneje se je njeno ime tam prvič pojavilo v recenziji zbirke dramskih besedil Ljubezen, ki jo je leta 1902 
objavil Milan Marjanović (1879-1955) v reviji Kolo. Marjanović je sicer recenziral že avtoričin prvenec Misterij žene (1900) in ga objavil v hrvaški Novi Nadi. ${ }^{2} \mathrm{~V}$ članku je Marjanović poleg njene knjige obravnaval tudi Knjigo za lahkomiselne ljudi (1901) Ivana Cankarja. Oba sta se recenzentu zdela najbolj markantni osebi sodobne slovenske književnosti, opazil pa je tudi podobnosti med njima: »Oboje žive van domovine: Kvedrova u Pragu, a Cankar u Beču. I to je važno zbog toga, što oni, ne živeći u sredini slovenačkog društva i njegovih dnevnih prilika, nego u velikom, slobodnom svijetu, gledaju na domaće prilike iz daljine, pa in vide preglednije, a ujedno ih mjere merilom velikog svijeta i mogu slobodnije da izražavaju svoja opažanja i svoje misli« (Marjanović 1902, 354). Čeprav kritik najde pomanjkljivosti tako v prozi Ivana Cankarja kot $v$ dramatiki Zofke Kveder je srbska kulturna javnost o obeh dobila pozitiven vtis, saj je avtor zaključil s pohvalnimi potezami:

»Jedno je jasno, a ujedno i od velikog značaja, i Zofka Kveder i Cankar ruše predrasude i laž, dižu potištene i ponižene, i traže novog čovjeka za nov, bolji, slobodniji i konsekventniji život. A takvi ljudi, novi, jaki, slobodoumni, potrebni su svakom narodu, kamo li malom slovenačkom narodu. Baš zato i vidim u Kvedrovoj i u Cankaru dio one opće narodnje težnje za novim ljudima, koji će narodu stvoriti bolje dane boljeg života, pa se zato i ne žacam, u prkos svih njihovih tobože kosmopolitskih ideja, smatrati ih piscima, koje su stvorile narodne prilike, precima narodnim, jednako slovenačkim, kao i našim hrvatskim i srpskim« (Marjanović 1902, 358).

Omenjena recenzija in številne druge, ki jih je Marjanović napisal za različne časopise, dokazujejo, kot je zapisal že Štefan Barbarič v sestavku o njem, da so se »mladi ustvarjalci v Ljubljani, Zagrebu, Beogradu in v jugoslovanskih literaturah nasploh zanimali drug za drugega, se med seboj podpirali v generacijski zavezanosti določenim skupnim idejam in ciljem modernističnega programa« (Barbarič 1980, 473).

Verjetno se zdi, da sta Marjanović in njegova recenzija tudi botrovala objavi besedila U zoru v reviji Slovenski jug leta 1903. ${ }^{3}$ Kasneje je Zofka Kveder $v$ tem časopisu objavila še dve pripovedni besedili -

\footnotetext{
2 Marjanović je iz Zagreba odšel v Beograd, o čemer piše Zofka Kveder v članku NovoNadaši, objavljenem v reviji Veda, leta 1913 (gl. tudi peti zvezek Zbranega dela Zofke Kveder): »Marjanović je odšel v Belgrad, organiziral nekak poloficiozen dopisni urad srbski za slovanske časopise in njegovo pero deluje zdaj za interese Srbije, a to pero je okretno in duhovito« (Kveder 2018, 522).

3 V Hrvatskem biografskem leksikonu so zapisani podatki, da je Zofka Kveder v srbskem tisku prvič objavljena leta 1910, v reviji Slovenski jug. Lenka Lečić je na doktorskem študiju pri prof. dr. Biljani Dojčinović (Univerza v Beogradu) ugotovila, da je prvo besedilo objavila že 1903. leta. Kot navaja $v$ elektronskem sporočilu avtorici članka, $v$ fondu knjižnice manjkata letnika 1905 in 1909, nepopolni so tudi letniki 1904, 1906, 1907 in 1908, zato ni mogla pregledati teh izvodov revije, v katerih je Zofka Kveder morda objavila še kaj. Omenjeni leksikon navaja še recenziji prozne zbirke Iskre. Podatek je le delno pravilen, saj je v Politiki izšel tudi prevod dveh avtoričinih kratkoproznih besedil (Sječajte se in Anka).
} 
Idila (1910) in Tuđe suze (1910) - obe besedili naj bi bila prevoda, ki ju je opravila oseba, podpisana z Dž. V časopisu Politika ${ }^{4}$ je v feljtonu leta 1905 objavila dve krajši pripovedni besedili iz dvojezične zbirke Iskre (1905): Sječajte se in Anka, ki sta bili obe že v knjigi objavljeni v hrvaščini. Izbor prvega besedila je morda temeljil na tem, da je že bilo prevedeno $v$ bolgarščino in je bilo objavljeno $v$ ugledni reviji $v$ Sofiji (Mihurko Poniž 2019), drugo je bilo morda izbrano zaradi kratkosti ali liričnosti, ki je $v$ nasprotju $z$ dogajalno bolj razgibano pripovedjo Sječajte se.V rubriki Književnost in umetnost je bila v isti številki objavljena tudi ocena zbirke. Anonimni recenzent je besedila označil kot sličice. Kot je zapisal, je Politika dve izmed njih objavila, da bi bralci videli, s koliko topline piše Zofka Kveder - avtorica, ki piše v jezikih dveh bratskih narodov. Dodal je tudi, da je v vseh njenih delih čutiti žensko srce, da se avtorica razdaja $z$ vso svojo dušo, kar je večinoma vrlina, a včasih zaradi tega knjiga deluje monotono. Pisateljičina občutljivost in iskrenost, kot še ugotavlja recenzent, dajeta zgodbam močan individualen pečat. Uredništvo knjigo toplo priporoča bralstvu tudi zato, ker jo je napisala predstavnica naroda, ki je blizu srbskemu (Politika, 4. maj 1905).

Druga recenzija je bila objavljena $v$ časopisu Delo ${ }^{5}$ in je bila tudi zelo naklonjena avtoričini knjigi. Tudi tokrat nepodopisani recenzent je zbirko označil kot najboljše pisateljičino delo, ki je še posebno dobrodošlo, ker je avtorica Slovenka.V recenziji je zapisano, da je avtorica odvrgla vse predsodke, ki utesnjujejo ženske, in osvojila zelo ugledno mesto $v$ književnosti. Besedila $v$ zbirki Iskre so označena kot pesmi $v$ prozi, poudarjeno je, da ne gre za zgodbe, temveč refleksije in psihološka opažanja. Med besedili je nekaj več pozornosti namenjene noveli Kajn.Zapis je zaključen z mislijo, da gre za simpatično knjigo, ki je pretkana z nežnimi, čistimi in čisto nič izumetničenimi občutji, polna je melanholije. Ker o njeni umetniški vrednosti ni dvoma, jo priporočajo bralcem (Delo, št. 35, 1905). Prisotnost Zofke Kveder v treh pomembnih

\footnotetext{
4 Politika je bila dnevnik, ki je pomenil pomemben dogodek v srbskem novinarstvu, saj je imela umirjen in uglajen način pisanja, distancirala se je od političnih časopisov, ki so zapadli v stankarske igrice. Bila je časopis za intelektualce, že nekaj let po izidu pa tudi najuglednejši in najbolj bran srbski časopis (prim.https://www.rastko.rs/isk/isk_20.html).

${ }^{5}$ Na portalu Istorijske novine o tej reviji beremo: »Časopis je izlazio mesečno u Beogradu od 1894. do 1899.; i od 1902. do 1915. sa podnaslovom List za nauku, književnost i društveni život. Takođe, bio je ugušen nasilno u vreme Ivanjdanskog atentata, dok je od juna 1914. do marta 1915. izdavanje bilo obustavljeno zbog rata. Časopis je bio u vlasništvu Radikalne stranke. [...] Najviše priloga je bilo iz književnosti, istorije i ostalih društvenih nauka, sa prikazima i ocenama knjiga. Upravo, ovaj časopis počeo je tamo gde je stala Otadžbina Vladana Đorđevića. lako časopis radikala, u njemu su sarađivali i pripadnici drugačijih stavova, te se među saradnicima pojavljuju i: Simo Matavulj, Branislav Nušić, Jaša M. Prodanović, Đorđe Stratimirović, Bogdan Popović, Janko Veselinović, Aleksa Šantić, Ivo Ćipiko, Vladislav Petković - Dis, Vladimir Ćorović, Aleksandar Belić, Nedeljko Divac, Josip Kosor, Sima Pandurović, Radoje Domanović, Branislav Petronijević i mnogi drugi« (http://www.unilib.rs/istorijske-novine/pregledlat?newspaper=UB_00048).
} 
srbskih periodičnih publikacijah pred prvo svetovno vojno dokazuje, da je bilo njeno pisateljsko delo tudi v srbski kulturi prepoznano kot pomemben prispevek. Na kakšen način je pisateljica svoja dela posredovala omenjenim revijam oziroma časopisu, ni bilo mogoče ugotoviti, saj med njeno korespondenco ni ohranjenih pisem, iz katerih bi bilo razvidno, ali je bila povabljena k posredovanju besedil, ali je Iskre sama poslala $v$ uredništvi obeh listov, kjer sta bili objavljeni recenziji.

Navedene objave niso bile edini stik Zofke Kveder s srbskim prostorom v prvem desetletju novega stoletja. Osmega novembra 1905 je bil na beograjskem odru t. i. južnoslovanski večer, ki se je predtem odvil že $v$ Zagrebu (sedemnajstega oktobra istega leta), vendar z nekoliko drugačnim izborom besedil. Bolgarsko dramatiko je v Beogradu predstavljal Petko J. Todorov z enodejanko Strahil, strašni hajduk, hrvaško Milan Begović z že v Zagrebu uprizorjeno Venus victrix, srbsko Vojislav J. Ilić s Pjesnikom, slovensko pa Zofka Kveder z Ljubeznijo. Ljudmila MaLinova Dimitrova je ugotovila, da so Ljubezen igrali v srbskem prevodu Vlada Stanimirovića, režiral je Milorad Gavrilović, igrali pa so Radomir Petrović (stari Koder), Jelena Gavrilović Petrović (ga. Koder), Bogoboj Rucović (Dušan), Aleksandra Bojićeva (Jelva) in Luka Popović (Branko). Drugi večer so vrstni red nekoliko spremenili (za bolgarsko enodejanko je bila slovenska), kar Ljudmila Malinova Dimitrova razlaga z vsebinsko povezanostjo obeh del: »Sprememba ni bila naključna, temveč ima svoj impliciten pomen. Najbrž se je publiki drama Zofke Kveder zdela najbližja bolgarski, in sicer glede na emocionalno vzdušje, ustvarjeno na odru, kot tudi glede na sorodne eksistencialne probleme in tipologijo dramskih situacij« (Dimitrova 2012, 176). Po uprizoritvi sta bili po navedbah L. M. Dimitrove objavljeni dve oceni: v Odjeku in Srpskem književnem glasniku. V Odjeku so najprej povzeli vsebino, vendar je bila obnova »naivna in lakonično opisuje dramsko dogajanje, poudarja sentimentalno-presunljivo interpretacijo teme o predani ljubezni v družini« (Dimitrova 2012,177). Kritiku se zdi neverjetno, da tako nadarjen mladenič, kot je Dušan, ne najde službe, s katero bi preživel svojo majhno družino, tudi razplet se mu je zdel neprepričljiv. Po mnenju navedene bolgarske teatrologinje kritik »ni opazil kompleksnosti situacije in njene polisemantičnosti, temveč je raje komentiral, ali se razplet dogajanja ujema z običajnimi življenjskimi dejstvi« (Dimitrova 2012, 177). V reviji Srpski književni glasnik je kritik med vsemi štirimi enodejankami izpostavil Ljubezen kot povsem drugačno delo, ki ima moderne poteze, globino in spominja na Maeterlincka, vendar se mu to ni zdelo simpatično, ali kakor zapiše Dimitrova v analizi njegove kritike: »Po njegovem mnenju manjka logika $v$ dokončni odločitvi staršev, da naredita samomor in na ta način rešita sina in njegovo zaročenko. $\mathrm{Na}$ koncu recenzije je kritik spet izrazil neodobravanje, a tokrat popustljivejše in rahlo ironično: 'Lepo bi bilo kad bi se roditelji ubijali čim jim je sin nervozan jedno veče!'« (Dimitrova 2012, 178). 
Naslednje leto (1906) je bil na prvi strani Pravde objavljen članek Ženskinje kod Slovenaca, ki je na kratko predstavil slovenske pisateljice. Zofka Kveder je bila označena kot popolna realistka, a v novejših delih tudi pristašinja simbolizma. Njene slike in zgodbe so znane $v$ nemški književnosti, nekaj jih je tudi v srbskih prevodih (Ženskinje 1906, 1).

Leta 1917 je Zofka Kveder v Beogradskih novinah objavila članek, ki ga je namenila vojakom. $\vee$ njem jih je prosila, naj hranijo pisma svojih mater in žena, saj bodo dragoceno zgodovinsko gradivo o vojni. 0 drugih objavah Zofke Kveder in poročilih o njenih delih nismo našli podatkov. Posebna oblika recepcije Zofke Kveder in njenega literarnega opusa v srbskem kulturnem prostoru so tudi nekrologi, o katerih bomo razmišljali na koncu članka.

\section{Ustvarjalno prijateljstvo - Dimitrij Tucović in njegova idealizacija v liku Kazimirja Staszyńskega v romanu Hanka}

Zofka Kveder je srbsko kulturno življenje gotovo pozorno spremljala, saj je bila goreča privrženka povezanosti slovanskih in še posebno južnoslovanskih narodov, vendar $v$ začetku drugega desetletja dvajsetega stoletja $v$ ospredje ne moremo postaviti njenih objav, saj nismo našli nobene iz tega obdobja. A to ne pomeni, da so njene vezi s Srbijo popustile. Nasprotno - srečanje s socialnim demokratom in velikim intelektualcem Dimitrijem Tucovićem (1881-1914) jo je zaznamovalo kot osebnost in kot pisateljico. Spoznala sta se med velikonočnimi prazniki leta 1914, ko je bil Tucović v Zagrebu. Najverjetneje se je Tucović družil z možem Zofke Kveder Jurajem Demetrovićem, ${ }^{6}$ ker sta si bila blizu po političnem prepričanju. Tako je Tucović preživel velikonočne praznike na obisku v Demetrovićevi hiši in na sprehodih z Zofko Kveder. Njuno medsebojno naklonjenost so opazili vsi, ki so ju obdajali, in celo Demetrović naj bi že ob prvem srečanju Zofke Kveder s Tucovićem dejal, da ne bo žalosten, če jo bo izgubil zaradi njega, saj je vreden, da ga ljubi.' Literarno je Zofka Kveder njuno srečanje opisala v sestavku Moj literarni konfiteor, ki se začne tako:

U uskrsnim danima 1914. pokazivala sam posetniku iz Srbije divnu i prekrasnu našu zagrabčku okolicu. Brda zagrebačka sa svojim lepim vrtovima bijahu sva bela i ružičasta od cvatučih voćaka. Mirisavi lahor igrao se sa korvčastom zlatnom kosom moje najmlađe kćerke, kojoj bijaše tada dve i po godine. Na visokome plavome proljetnjome nebu oštro se crtahu konture zagrebačke gore.

\footnotetext{
6 Juraj Demetrović (1885-1945) se je po študiju prava pridružil socijalističnemu gibanju in bil od leta1907 urednik strankinega dnevnika Slobodna riječ. Po prvi svetovni vojni je bil pomemben politik, leta 1945 je bil zaradi sodelovanja z okupatorjem obsojen na smrt.

7 Pismo Zofke Kveder Marthi Tausk, 4. 12. 1914, zapuščina Zofke Kveder, Ms 1113, Rokopisni oddelek Narodne in univerzitetne knjižnice Ljubljana.
} 
Mi smo išli prema Prekrižju svaki čas zastajkujući, da se obazremo i nauživamo divnog vidika na beli grad pod nama i na široko savsko polje, na kojem se svetlucala reka ko rastaljeno srebro. »Čujete, gospođo, a zašto vi ne pišete večih stvari?« zapita me Srbijanac.

»Tako, ne mogu. Pišem feljtone, crtice ...«

»Trebali biste svakako, da napišete štogod većeg. Pođite na putovanje po Makedoniji, saberite materijal i napišite roman o balkanskim ratovima," kaže mi moj pratioc mirno i ozbiljno. Ja se nasmejem. Glasno se nasmejem (Kveder 2016, 412).

Tucović se je na njen smeh odzval z jezo, saj je menil, da je znak zagrebškega cinizma, ki ubija talente. Toda ona mu je razložila, da se je smejala zato, da ne bi jokala, saj je žalostna, ker ne čuti moči, da bi se lotila večjega dela, da so ji tudi ob novelah, ki jih je pisala o balkanskih vojnah, kritiki očitali, da nima sposobnosti opisovanja epske širine. Tucović jo zavrne, da to ni res, saj je on bil na bojišču in ve, da je vojne dogodke odlično opisala, zato jo poskuša opogumiti:

Verujte opet u sebe i u svoju snagu. To je potrebno. I nije obmana. Ja vam to kažem, koji dobro poznajem ljude - u vama ima mnogo snage, još neizcrpljene! Imate talenta. To treba sve dignuti, korisno upotrebiti! To vam je dužnost! Mi smo tako mali, mi Jogoslaveni, zato treba da se do kraja iscrpi snaga svakog pojedinca. Članovi jednog malog naroda moraju sve da dadu iz sebe do krajnih granica, samo tako možemo, da se održimo. To je dužnost svakoga od nas! - I zato vam opet kažem: Vi ćete ići u Makedoniju, pokupiti ćete podatke, materijal i onda sednite i pišite! Eno vam zadaće! Dat' ču vam svoj dnevnik iz prvog i drugog balkanskog rata, da vam olakšam posao (Kveder 2016, 413).

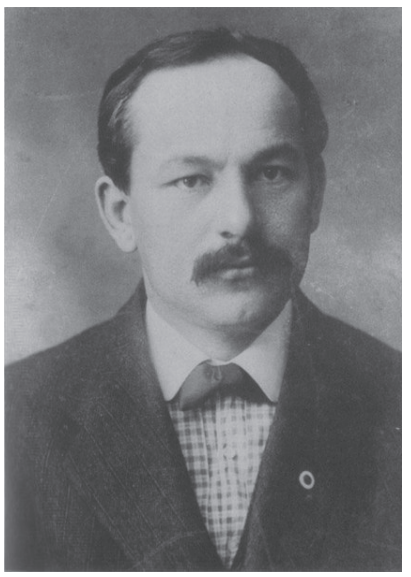

Slika 2 - Dimitrije Tucović.

https://sh.wikipedia.org/wiki/Dimitrije_Tucovi\%C4\%87\#/media/Datoteka:Dimitrije_ Tucovicc.jpg 
Zofka Kveder se je po tem srečanju počutila sposobno, da se loti tudi večjega besedila, a ni izbrala vojne tematike, temveč intimno zgodbo trpeče ženske. Roman je na koncu prejel naslov Njeno življenje (1914) in nagrado Slovenske matice, ki je pisateljici omogočila potovanje po Balkanu, kjer je želela zbrati gradivo za načrtovani roman o balkanskih vojnah, a so ji zgodovinski dogodki to preprečili:

Onog istog leta 1914. podoh u Srbiju in Makedoniju. Imam loše pamčenje pa ne mogu reči kako mi je žao onih slavnih pričanja, koja sam čula na svome putu i koja zatrpana kasnijim događajima leže na dnu moje duše. Koliko mi je žao onih raznih spiskova in notica, na bojnim poljima nadenih, zamrljanih pisama srpskih vojnika i mnogih prekrasnih pesma, koje su posle slavnih pobeda nikle $u$ narodu. Sve sam morala da ostavim preko u Beogradu, kad sam poslednjom rumunjskom ladom morala da preplovim u Zemun, da se vraćam kući. Počeo je svetski rat (Kveder 2016 , 414).

Pred potovanjem si je s Tucovićem izmenjala še nekaj pisem, ${ }^{8}$ iz katerih je razvidno, da se je med njima kljub kratkemu srečanju spletla prijateljska vez. Tucović ji je namreč poslal, kakor je ona napisala, zelo lepo pismo, ki se ni ohranilo, in mu priložil tudi svojo sliko. O njej je zapisal "gruba je ali je moja«, na kar mu je ona v pismu 18. junija odgovorila: »Moje oči vide poznato simpatično lice, a Vašu nutrinu upoznala sam po Vašim pripovijestima i pismu, a ta je vrlo lijepa i plemenita«. Zaključila je z upanjem, da je iz pisma razbral, da ga visoko ceni in spoštuje. Podpisala se je »Vaša Demetrović« (Tucović 1974, 403). Iz ohranjenega Tucovićega pisma Juraju Demetroviću je jasno, da je bilo najprej načrtovano, da gresta na potovanje skupaj z možem, a je nato zaradi njegove zaposlenosti padla odločitev, da se ji pridruži v Skopju, kjer bosta nadaljevala potovanje skupaj proti Solunu in nazaj po morju do Trsta. Tucoviću v pismu 23. junija poroča, da bo odpotovala prvega julija, ker je vzela dopust in ker se želi dlje zadržati $\vee$ novih srbskih krajih. ${ }^{10}$ Prosi ga, da naj ji prvega julija rezervira sobo v hotelu Moskva, $\checkmark$ najvišjem nadstropju $z$ razgledom na savsko ravnino. Ostala naj bi dva dni oziroma tri noči: »S toga molim, da mi saznate za adrese: 1. slovenskog društva, 2. Izidore Sekulićeve i jedne slikarice«. Najavlja, da bo prišla ponoči in prosi, da jo počaka na kolodvoru. Zapiše še, da komaj čaka, da se vsega reši in se podpiše kot Zofka.

Pred njenim potovanjem je med Beogradom in Zagrebom potovalo vsaj še eno pismo, v katerem je Tucović napovedal, da ga morda $v$

\footnotetext{
8 Ta pisma so zbrana v knjigi Tucovićeve korespondence Prepiska (Tucović 1974).

${ }^{9}$ Zapuščina Zofke Kveder, Ms 1113, Rokopisni oddelek Narodne in univerzitetne knjižnice Ljubljana.

${ }^{10}$ Mišljeno je ozemlje, ki ga je Srbija dobila po balkanskih vojnah.
} 
začetku julija ne bo v Beogradu, saj mu ona 26. junija piše, da bo zelo grdo, če ne bo počakal nekaj dni, da pride $v$ Beograd, in da je ravno na karti z rdečo začrtala drugi »popolni« itenerarij in vključila še izlet iz Skopja na Kosovo ter potem iz Bitole v Solun. Na poti v Skopje je hotela videti še Kragujevac, Niš, Vranje in Kumanovo. Prosila ga je, naj ji napiše detajlni načrt mest in krajev, kjer naj se ustavi, in koliko časa potrebuje za oglede. To mora vedeti iz časovnih in finančnih razlogov. Sporoča mu tudi, da namerava za hrvaško revijo Književne novosti napisati »Dojmove s puta«, kar bodo beležke za daljšo pripovedno delo, ki bi ga napisala čez zimo. Dobro bi bilo, mu še piše, da bi se o tem pogovorila in bi jo še malo navdušil ter ji vlil poguma za pot. Dodaja še, da bo v primeru, da se ne vidita, potovanje začela z nekim dvomom, da je ljudje ne bodo tako lepo sprejeli, kot je upala, in bo zaradi tega zadržana, potovanje pa ji ne bo toliko pomenilo. Zaključi z besedami: »Nemojte mi pisati »prijateljice Kveder«, ma to je užasno čuti i čitati! Mene sve zove Zofkom, svuda gdje god sam bila. »Kveder« - uvijek se moram tek sjetiti da se to mene tiče .....

To je zadnje ohranjeno pismo Zofke Kveder Dimitriju Tucoviću, a v pismu, ki ga je pisala tretjega julija iz hotela Moskva možu, ko je prispela v Srbijo, lahko povzamemo, da Tucovića res ni bilo v Beogradu, a je na kolodvor poslal študentko Milico Đurić (Zofka Kveder je njeno ime zapisala Gjurić), ki je kasneje postala ena izmed najbolj prepoznavnih srbskih feministk. ${ }^{11} \mathrm{~V}$ pismu je bila predstavljena kot »jedna mala študentica i organizatorica ženskog rad. pokreta«. Pisateljica je napisala o njej še naslednje: »Zgodna je, inteligentno izgleda, umiljate oči imade i veoma je vrijedna. »Partiji« sigurno više koristi nego što ću ja ikada. Inače mi izgleda za svoje godine staro. Imade tek 20, a ja sam mislila barem 24. Uz mene izgleda sitna i mala. A uz Tucovića je sigurno kao dijete. ${ }^{12}$

Tucović je v njenih mislih nasploh zavzemal osebo, ob katero je postavljala vse druge, saj je možu pisala: »Milica mi se svidja, pa Pavle Pavlović, ${ }^{13}$ onda taj Živko ${ }^{14}$... izgleda junački te imade jako lijepe bele

\footnotetext{
11 Milica Đurić Topalović (1893-1972) je diplomirala na Univerzi v Beogradu in doktorirala na Univerzi v Ženevi s področja pedagogike. Že leta 1911 je postala urednica ženskega časopisa Jednakost, od leta 1914 je sodelovala pri časopisu socijalistov Borba, po prvi svetovni vojni je imela številne funkcije v socijalistični stranki. Bila je članica Komunistične partije Jugoslavije, a je leta 1920 podpisala manifest proti Komunistični partiji in bila izključena iz nje. Aktivna je bila kot ustanoviteljica delavskega izobraževanja in številnih letovišč za otroke. Med vojno sta z možem sodelovala pri četniškem gibanju, D.Mihajlović ju je poslal na diplomatske misije v Italijo. Po vojni sta bila ujeta, a nista bila izročena jugoslovanskim oblastem. Do konca življenja sta živela v emigraciji, na Dunaju.

12 Pismo Zofke Kveder Juraju Demetroviću, 7. julij 1914.Zapuščina Zofke Kveder, Ms 1113, Rokopisni oddelek Narodne in univerzitetne knjižnice.

${ }^{13}$ Pavle Pavlović (1888-1971), kasneje znan komunist in revolucionar.

${ }^{14}$ Verjetno gre za Živka Topalovića (1886-1972), kasnejšega moža Milice Đurić Topalović, ki je bil tudi Tucovićev prijatelj.
} 
zube. Ali Tucoviću naravno nitko nije par. On je najkulturniji od njih svih, svestran i baš toliko djetinast, da mi se svidja./.../Zaljubit se neću. Tucovića, koji bi mi jedini mogao biti malko, malko opasan, i onako nema, a on je i u tome pogledu veoma čestit čovjek. Ona historija sa nekom Dragom i njegovim dijetetom koja bijaše u »Balkanu« neistinita je od početka do konca. $\aleph^{15}$

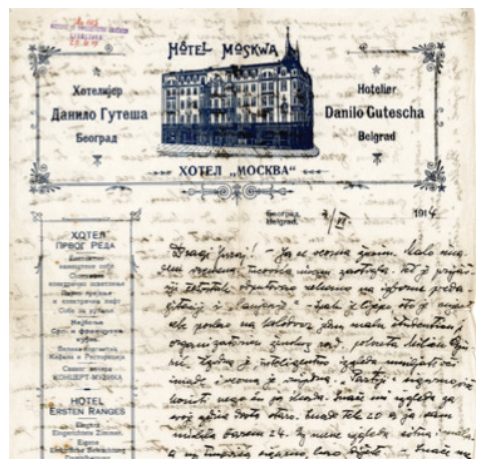

Slika 3 - Pismo Zofke Kveder možu Juraju Demetroviću iz Beograda na pisemskem papirju hotela Moskva, 3. julij 1914. Vir: Rokopisni oddelek Narodne in univerzitetne knjižnice Ljubljana, Zapuščina Zofke Kveder, Ms 1113.

Na potovanju po Srbiji naj bi Tucovića vendarle na kratko srečala, a le za dve uri, kot je pisala prijateljici Marthi Tausk. Češki prijateljici Zdenki Haskovi pa je o tem srečanju napisala: »Ko sem bila na potovanju, sva se videla samo za 4 ure. Spremil me je na parnik, s katerim sem se vrnila nazaj. - Povedal mi je o svoji slutnji, da se ne vrne z vojne, da ga boli pri srcu in da takšnih občutkov še nikoli ni imel.« ${ }^{16}$

Takšna so dejstva o njunem kratkem poznanstvu, saj se nikoli več nista srečala, a $v$ pisateljičinem delu je njegov lik zaživel na novo. Tucović je takoj ob začetku vojne šel na fronto in padel že v prvem letu bojev, dvajsetega novembra 1914. V domišljiji je Zofka Kveder to poznanstvo spremenila $v$ globoko ljubezen in jo naredila za rdečo nit romana Hanka. Roman je napisan v obliki pisem, ki jih naslovni lik piše prijatelju Kazimirju Staszyńskemu na fronto. Seveda je v Kazimirju upodobila Tucovića, ki mu je pridala še nekaj potez idealnega moškega iz svoje domišljije. Primerjajoč pisma Zofke Kveder in odlomke romana, je mogoče podobnosti zelo hitro odkriti: »One jeseni digla je neka podla klika kod nas veliku hajku protiv Vas, da obori uspjehe Vašega rada, koji ne bijahu u prilog njezinim tamnim ciljevima. /.../Tvrdili so,

\footnotetext{
${ }^{15}$ Pismo Zofke Kveder Juraju Demetroviću, 7. julij 19014. Zapuščina Zofke Kveder, Ms 1113, Rokopisni oddelek Narodne in univerzitetne knjižnice.

16 Pismo Zofke Kveder Zdenki Haskovi, 26. 11. 1914, Literarni arhiv Zagreb. Navajamo iz prevoda pisma, objavljenega v Jesterle-Doležal 2014, 331). V nadaljevanju navajamo odlomke iz navedene knjige.
} 
da ste denuncirali neke svoje drugove, samo da sebe spasite od Sibirije. Da ste podmitljivi, da ste se nepoštenim putovima dočepali imutka. Da ste zaveli neku jadnu študenticu, imenom Stanislavu, koja se kasnije sa svojim detetom bacila u vodu ...« (Kveder 1917,123).

Marthi Tausk je pisala, da je bil Tucović človek, kot ga še ni poznala, dal ji je toliko moči kot še nihče pred njim. Zdelo se ji je, da tistega, kar je doživela ob njem, čeprav se nista nikoli poljubila ali govorila o ljubezni, sploh ni mogla izraziti z besedami. Nikogar ni občudovala kot njega, bil ji je telesno in duševno ideal moškega, v pogovoru z njegovimi tovariši je ugotovila, da o njem ve več kot oni. Ko ga je srečala $v$ Srbiji je izžareval harmonijo. Tucović je imel, kot še piše, sijajen razum, bil je otroško čist in srčno dober, njegove roke so bile čudovito lepe, o njih je sanjala. ${ }^{17} \mathrm{O}$ tem je pisala tudi v Hanki: »Nikad vam još nisam rekla, kako mi se svidjaju Vaše ruke. To su najlepše ruke, što sam in ikad vidjela, žive ili naslikane. Najduševnije in najsavršenije formom. Tako su velike i jake. I tako su dobre, mirne, plemenite. Kadgod ih pogledam, osjetim, kako svakome mogu, a i hoće da pomognu, kako svakoga umire« (Kveder 1917, 42). Tudi v pismih Zdenki Haskovi piše o Tucoviću kot o svojem idealu: »Lahko sem mu hvaležna za marsikaj. O, morda je dobro, da ga nikoli nisem spoznala bližje. Tako mi bo za vedno ostal ideal «. ${ }^{18}$ Roman Hanka je hvalnica podobi moškega, ki si ga je po nekaj srečanjih in po nekaj pismih ustvarila Zofka Kveder. ${ }^{19}$ Ob novici o njegovi smrti je Haskovi četrtega decembra 1914 pisala: »Prebudila sem se ponoči z občutkom, da leži na mojem obličju njegova velika in mirna roka« (Jensterle Doležal 2014, 242).

O njeni naklonjenosti Tucoviću se je ohranilo še nekaj pričevanj. Alenka Jensterle Doležal opozarja še na pismo, ki ga je pisateljica pisala na Češko 22. oktobra 1917: „Včeraj sem dobila pismo od Milice, v pismu govori o Dimitriju. Kako sem ga pričakovala. A niti zdaj ni napisala podrobnosti, po katerih tako hrepenim. Samo, da je ta dan, ko sem ga videla zadnjič, govoril z njo in ji rekel, da me ljubi. Prosil jo je, da bi poskusila izvedeti kaj o meni - preko Bolgarije in ko ji je to uspelo, je bil že mrtev ... Za vse na svetu bi hotela izvedeti kaj več o njegovem dnevniku. To čakanje me ubija« (Jensterle Doležal 2014, 328).

Na Rokopisnem oddelku Narodne in univerzitetne knjižnice Ljubljana hranijo knjigo Pelle, der Erober (1906-1910), ki jo je napisal

\footnotetext{
17 Pismo Zofke Kveder Marthi Tausk, 4.12.1914,zapuščina Zofke Kveder, Ms 1113, Rokopisni oddelek Narodne in univerzitetne knjižnice Ljubljana.

${ }^{18} \mathrm{Gl}$. opombo 14 .

19 Toda mit o njuni globoki povezanosti je Zofka Kveder s Hanko uspešno zapisala $\checkmark$ kulturni spomin. $\vee$ pomanjkanju podatkov o ljubezenskem življenju Dimitrija Tucovića je bila namreč $v$ nadaljevanki o njem, predstavljena kot ena izmed žensk $\mathrm{v}$ njegovem življenju. Več o nadaljevanki gl. https:/www.imdb.com/title/tt0199209/ fullcredits?ref_=tt_cl_sm\#cast
} 
Martin Andersen Nexø (1869-1954) in je bila zaradi svojega sporočila o pomenu delavskega gibanja $v$ socialističnih krogih zelo popularna. Na prvo stran v knjigi je Zofka Kveder zapisala, da jo je za velikonočne praznike posodila Tucoviću in jo je on vzel s seboj na fronto. Kot je še razvidno iz zapisa, je spomladi leta 1918 Milica Đjurić Topalović knjigo našla pri nekih kmetih in ji jo leta 1920 vrnila.

V reviji Danas je Momčilo Đorgović leta 2016 zapisal, da naj bi po Tucovićevi smrti Zofka Kveder pisala njegovi sestri Dragici naslednje besede: »On mi je dao veru u život, bila sam u njega zaljubljena«. Poslala ji je tudi svoj roman Hanka z naslednjim pripisom: »[M]islim da ćete na stranicama ove knjige prepoznati svoga brata«. Tucovićeva sestra ji je poslala njegovo zadnjo fotografijo in dobila odgovor: »Neobično sam srećna što imam sliku vašeg brata«. ${ }^{20}$

O tem, kako visoko je Zofka Kveder postavila Dimitrija Tucovića, priča tudi psevdonim Dimitrije Gvozdanović, ki si ga je izbrala za svoja dramska besedila, napisana po drugi svetovni vojni.

\section{Neprecenljiva izkušnja potovanja po Srbiji}

V Srbiji Zofka Kveder ni le navezala stika s srbskimi socijalisti in socijalistkami, temveč je spoznala tudi druge intelektualne osebnosti. V decembrski številki Jugoslovanske žene se je leta 1918 tako spominjala potovanja:

U ljeti 1914. bila sam u Srbiji. Htjela sam, da pogledam ratišta Kumanovo polje, Babuna planinu, Prilepsko polje, Bitolj. Bila sam i u Solunu. Neke divne ljetne noći vozila sam se obitelju jednog solunskog Srbina tada praznim i pustim solunskim zaljivom./.../ Putovala sam u Bitolj pa opet natrag u Skoplje, a onda odande na Kosovo polje i u Prizren. I tamo u Prizrenu na granici Albanije rekoše mi, neka žurim natrag, jer je Austrija naredila mobilizaciju, a i Srbija da mobilizira i da će biti rata.

Možete mi vjerovati, da na svome putovanju nisam čitala nikakvih novina, jer sam htjela, da što više vidim od onih romantičnih krajeva, da razgovaram sa štoviše ljudi iz naroda. Vratila sam se u Prizren preko visokih i divljih ogranaka Šar planine, mimo starodrevnih turskih hanova, pa preko Ferizovća na Kosovu polju natrag u Skoplje. Bila sam gošćom Branislava Nušića. Onu većer nije bilo više moguće otputovati pa sam pošla sa Nušićevima u kuću skopljanskog gimnazijalnog direktora Popovića, gdje se je sabralo veliko društvo, da se medjusobno bodri i tješi. /.../ Tek drugi dan sam mogla da putujem dalje preko Kumanova, Vranje i Niša u Beograd (Kveder 1918, 476-477).

20 Momčilo Đorgović: Dimitrije Tucović: Miris žene https://www.danas.rs/nedelja/ dimitrije-tucovic-3-miris-zene/ 


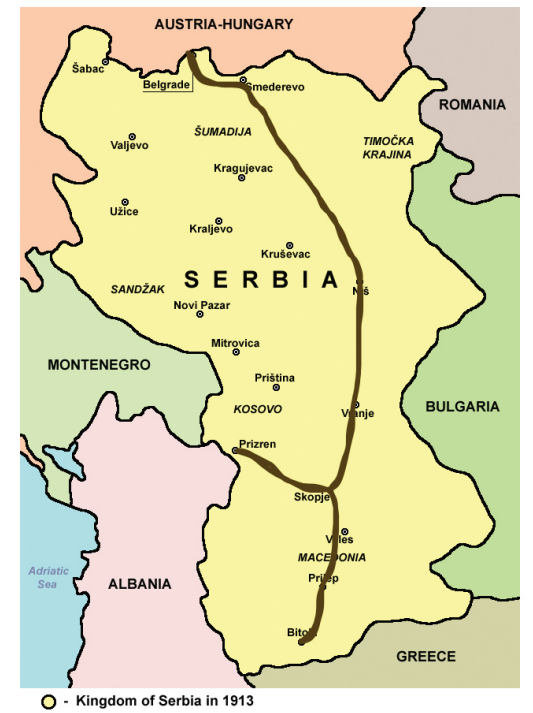

Slika 4 - Simbolični zemljevid potovanja Zofke Kveder po Srbiji, julija 1914. Vir zemljevida: https://sh.wikipedia.org/wiki/Kraljevina_Srbija\#/media/ Datoteka:Serbia1913.png. Pot je zarisala avtorică članka.

Iz Beograda se je odpravila v Niš, o čemer priča pismo Juraja Demetrovića, v katerem je zapisan kraj in datum pisma (Niš, 6. julija) in kjer med drugim piše o srbski gostoljubnosti: »Svi su otvoreni i srdačni prema meni«. Naslednji dan, sedmega julija, je obiskala Kumanovo in hčerki Vladoši na razglednici zapisala: »Danes sem bila pri bulah v starih turških hišah. Lahko si misliš, koliko romantike je tukaj povsod na vsakem koraku. Sledovi vojsk povsod se še vidijo. Zdaj grem »na položaj«, od katerega se vidi ves tok boja pri Kumanovem«. Še istega dne ji je poslala še eno razglednico, na kateri je kostnica Ćele Kula v Nišu. Osmega julija je pisala že iz Skopja: »U Kumanovom gdje bijah jučer. /.../ Danas rano izvezli su me - neki major - van Kumanova i kazivali ratno polje te objašnjavali poziciju bitke. Sada sam tu kod Nušićevih. Skoplje je interesantan grad, pomalo naliči na Sarajevo. Lepši je od Niša. Na Kosovo polje ide Margita skupa sa mnom. /.../ U Prizren neču iči ni na Ohrid, nego direktno iz Bitolja u Skoplje«. ${ }^{21}$

Tudi devetega julija se je hčerkam javila s kratkim sporočilom, ki priča o njeni navdušenosti nad potovanjem: »Drage moje! Veoma sam sretna, što sam došla na put ovamo dole. Mnogo novih utisaka mi krasi gotovo svaki sat«. ${ }^{22}$

\footnotetext{
${ }^{21}$ Pismo Zofke Kveder Juraju Demetroviću, 6. 7. 1914, Zapuščina Zofke Kveder, Rokopisni oddelek Narodne in univerzitetne knjižnice Ljubljana.

22 Razglednica Vladoši Jelovšek, 8. 7. 1914, Zapuščina Zofke Kveder, Rokopisni oddelek Narodne in univerzitetne knjižnice Ljubljana.
} 
V Skopju je ostala več kot teden (Vladoši 11. 7. od tam pošlja kartico), osemnajstega julija so se z avtomobilom najprej odpeljali v Bitolo in nato v Prilep, dvaindvajsetega julija pa si je ogledala Prištino. Brez datuma je razglednica hčerki Vladoši iz samostana Gračanica. Iz pisem, ki jih je pisala možu, je razvidno, da je vse te izlete delala iz Skopja, kjer se je vedno bolj čutilo, da se pripravlja nekaj velikega. Ob vojni napovedi je zato $v$ naglici odpotovala $v$ Beograd in se $v$ Zemunu vkrcala na ladjo proti Hrvaški. Spomini na ta doživetja pa so $v$ pisateljici še dolgo živeli, saj je v recenziji zbornika Slovenska žena zapisala:

Ista imena, ki so jih nosile od 900.1. p. K. in dalje Slovenke, žive še danes po južni Srbiji. V vaseh okrog Skopja, Velesa in Bitolja, na Kosovem polju in tam ob silni stari albanski meji v Prizrenu - povsod so mi po svobodnih in čiftinskih iz pleterja in blata spletenih vaseh donela na uho mila imena: Tihica, Ljuba, Dražica, Vesela, Kosa, Lepa, Vila in Iverka - ki so jih Slovenke nosile pred tisoč, devetsto in osemsto leti po štajerskih in koroških ravnicah in hribih. Kako so mi v Makedoniji ugajala ljubko naivna imena: Ljuta, Zla, Dobra, Zemidraga i slična. /.../V skopljanski Črni gori nad Skopjem nosijo žene in dekleta še zdaj platnene bele obleke, vse s črnimi ornamenti vezene; spomin na kosovsko tragedijo, kakor nosijo v hrvatskem Primorju Primorke na žgočem soncu črne halje, v spomin na smrt Frankopanov (Kveder 2018, 561-562).

\section{Korespondenca s srbskimi prijateljicami}

V kratkem obdobju potovanja po Srbiji je Zofka Kveder navezala veliko stikov, ki so se kasneje nadaljevali tudi preko pisem. Za Zofko Kveder so pisma pomenila pomemben način izražanja pogledov na svet, komentiranja umetniških del in dogodkov ter dajanja medsebojne podpore, kakor je razvidno iz njenih literarnih in publicističnih besedil:

Ljubim pisma kakor nekaj živega, osebnega. Kakor glas so, ki pride iz dalje, kakor topel, pozdravljajoč pogled, ki zbudi v srcu nekaj radostnega in svetlega. Včasi so kakor zdrav, vesel, odkritosrčen smeh, drugič zopet kakor melanholična melodija, ki jo posluša človek v mraku, sanjajoč in otožen (Kveder 2013, 7).

Kdaj je človek najbolj odkritosrčen, kdaj se najbolj razodene, kdaj najbolj brez strahu odgrne svojo dušo? - Morda v pismih, morda $v$ dnevnikih.

In vidite, zato jaz nadvse ljubim čitanje dnevnikov in pisem. Tam čutiš toplino tujega življenja, utripe tujega srca, duhaš cvet tuje duše, če so pisma res odkritosrčna. A to se čuti.

Zato so mi pisma nekaj svetega in čitam jih s spoštovanjem, ki je globlje, čim je pismo bolj odkritosrčno, toplo in neposredno (Kveder 2018, 542). 
Kot pisateljica je za izražanje svojih misli večkrat uporabila pisemsko obliko v člankih, ki jih je pisala o svojih obiskih tujih mest (Pismo iz Curiha, Pismo iz Prage itn.), a tudi v literarnih delih. V zgodnji roman Nada (1903) je vstavila nekaj pisem v smislu pisemskega romana, roman Hanka (1917) pa je v celoti napisan v obliki pisem naslovnega lika. Glede na zapisano tako ni presenetljivo, da velik del zapuščine Zofke Kveder sestavljajo pisma: njena in njenih korespondentov in korespondentk. Njena korespondenčna mreža je zelo bogata, obsega dopisovalke in dopisovalce iz osrednje in jugovzhodne Evrope in sega celo čez Atlantik. Večina pisem srbskim prijateljicam je danes izgubljena, a iz tistih, ki so ohranjena, si lahko ustvarimo podobo pisemskega omrežja Zofke Kveder na Balkanu. V srbskem prostoru so bile z Zofko Kveder povezane, kakor lahko razberemo iz ohranjene korespondence, predvsem avtorice in feministke. ${ }^{23}$ Iz njihovih pisem je razvidno, da so jo spoštovale zaradi feminističnega angažmaja in osebnostne integritete. Tudi ko so se njihova politična in socialna naziranja razlikovala, jih je družila zavest o ženski podrejenosti in želja po osvoboditvi žensk ali kakor je zapisala Milica Đurić Topalović: »[T]i znaš da si ti meni draga, da naši raznoliki socijalni i politički pogledi tu nemaju vrednosti; oni ne mogu deliti nas kao žene, jer je nama obema dvoje zajedničko: potištenost silna i želja za dizanjem i oslobođenjem: susreti su stvar sporedna«. ${ }^{24}$

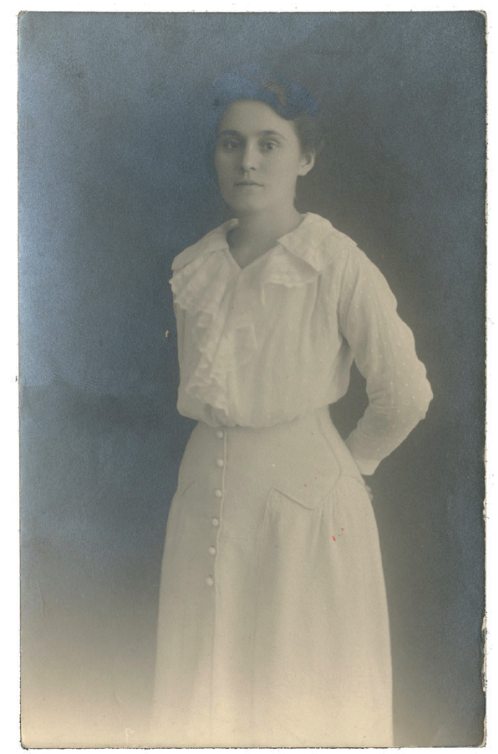

Slika 5 - Milica Đurić Topalović

Rokopisni oddelek Narodne in univerzitetne knjižnice Ljubljana, Zapuščina Zofke Kveder, Ms 1113.

\footnotetext{
23 Zahvaljujem se Vladimirju Đurić in Mariji Bulatović, raziskovalcema na projektu Knjiženstvo, ki sta pomagala pri transkripciji korespondence.

24 Pismo Milice Đurić Topalović Zofki Kveder, 1. januar 1922. Zapuščina Zofke Kveder, Ms 1113, Rokopisni oddelek Narodne in univerzitetne knjižnice.
} 
Njihova podpora je bila posebno pomembna, ko je Zofka Kveder začela izdajati feministično revijo Ženski svijet, saj so ji pomagale z iskanjem naročnic. Pisateljica Vera B. Tanazević (?-1936), ${ }^{25}$ ki je svoja literarna besedila objavljala tudi v Ženskem svijetu, ji je razkrila v pismu svojo slabo vest, da na kongresu Jugoslovank ni vstala in se ji zahvalila za vse tisto, kar je $v$ vojnem času naredila za ženske interese. Piše ji tudi, da občutek sestrstva, ki ga je Zofka Kveder začutila v odnosu do Američanke Rosalie S. Morton, ${ }^{26}$ čuti ona do nje in jo imenuje veliko sestro ter ji vliva pogum $v$ trenutkih obupa:

Ja verujem, da je teško to doživeti I tim se pomiriti, ali to bi teško bilo kakvoj maloj ženici, koja je zavisna od braka, muža, društva. Ali Ti Zofka? Seti se šta si bila pre, šta si sve mislila i govorila ... pisala, dok te bolest nije oborila, pa ćeš videti da digneš glavu i sa visine da gledaš na život I svoj položaj u njemu. Ti nisi sama. Ljubav tvoje dece I tvojih prijatelja neka te hrabre. Piši mi skoro, sestrice, brinem za tebe. Uvek tvoja Vera. ${ }^{27}$

Aktivistka, urednica in pisateljica Zorka Janković (1870-1933) ji je pisala, da je ona, Zofka Kveder, prispevala k ideji, da ženska postane človek, in da lahko samo skupaj napravita še več:

Molim Vas, priberite se! Ako nije istrošena vaša fizička snaga, duševno ne smete kloniti! Pogledajte oko sebe i da ima mnogo da se učini da bude bolje - da bude posve dobro. Je samo onaj, tko poznaje zlo zna za razliku između dobrog i zla. I ja sam trpila, trpim i bunim se - neka meni bude bolje - ne, zato je kasno, nego da ni jednoj ženi na svetu ne bude više ovako kako je meni. /.../ I ja verujem da če tako biti.Jer jednako je velika naša želja da vidimo reformisano ljudsko društvo u kom če I žena biti čovek. Vi ste do danas mogli doprineti tome više nego ja. Blago Vama. Istrojte, molim Vas. Pomagaći Vas svim silam, bez Vas ali, neću moći učiniti ništa, iako bih doista mnogo - mnogo htela. ${ }^{28}$

\footnotetext{
${ }^{25}$ Letnice rojstva ni bilo mogoče ugotoviti.

${ }^{26}$ Zdravnica in feministka Rosalie Slaughter Morton (1876-1968) je z Zofko Kveder navezala stik med svojim bivanjem v Jugoslaviji, najverjetneje v Beogradu, kjer je bila večkrat po prvi svetovni vojni, v kateri je bila bolničarka na solunski fronti. $\vee$ Srbiji je ustanovila tri bolnice in Srbski komite, ki je pomagal mladim na poti do izobrazbe. $\checkmark$ Beogradu sta ji posvečena park in ulica. Ko se je vrnila v Ameriko, je vzpostavila dopisovanje z Zofko Kveder.

27 Pismo Vere B. Tanazević Zofki Kveder, 3. februar 1920. Zapuščina Zofke Kveder, Ms 1113, Rokopisni oddelek Narodne in univerzitetne knjižnice.

${ }^{28}$ Pismo Milice Janković Zofki Kveder, 24. januar 1918. Zapuščina Zofke Kveder, Ms 1113, Rokopisni oddelek Narodne in univerzitetne knjižnice.
} 
Tudi srbska svetovna popotnica in pisateljica Jelena J. Dimitrijević (1862-1945) je bila del njene pisemske mreže, saj ji je na razglednici pošiljala pozdrave in zraven zapisala, do jo zelo ceni. ${ }^{29}$

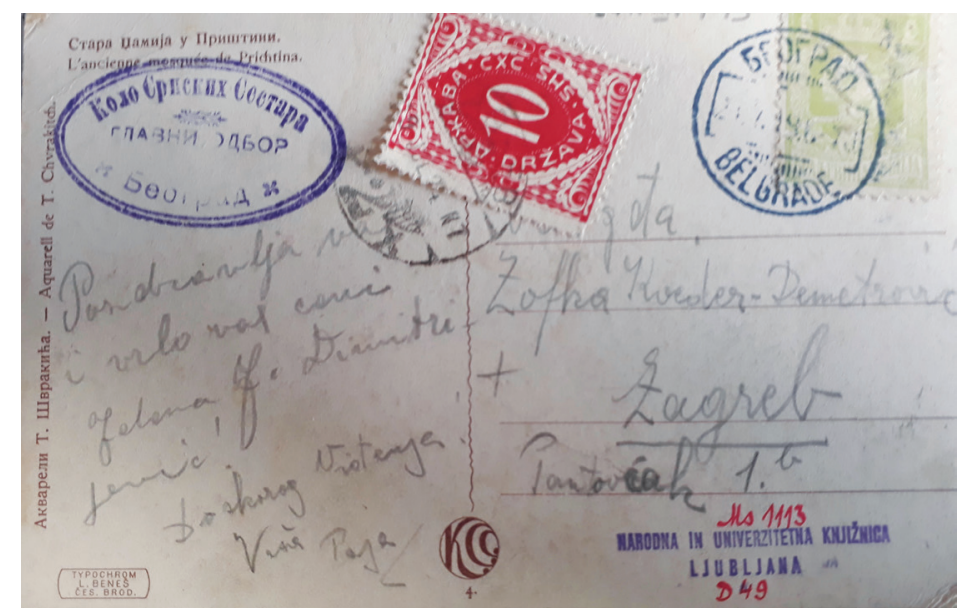

Slika 6 - Razglednica Jelene J. Dimitrijević z žigom Kola srpskih sester Rokopisni oddelek Narodne in univerzitetne knjižnice Ljubljana, Zapuščina Zofke Kveder, Ms 1113.

Iz pisma Jelke Todorović30 je razvidno, da je Zofka Kveder v Beogradu obiskala tudi pisateljico Milico Janković (1870-1933). K njej jo je pripeljala Dobroslava Đorđević, ${ }^{31}$ prijateljica srbskega socialnega demokrata Dimitrija Tucovića: »Razgovarale smo dosta o Vama, g-đica Janković Vas se prijatno seća i kaže, da neće lako zaboraviti onaj dan, kada Vas je k njoj dovela g-ca Dobroslava Đorđević, jer to posle podne imala je strašnu glavobolju, ali od Vaših zanimljivih priča sve joj je brzo prošlo i ona je žalila, kada ste otišli, da niste još duže kod nje bolesne ostali«. ${ }^{32} \mathrm{Da}$ je bila naklonjenost obojestranska, je razvidno

\footnotetext{
${ }^{29}$ Razglednica Jelene J. Dimitrijević Zofki Kveder, 21. avgust 1919. Zapuščina Zofke Kveder, Ms 1113, Rokopisni oddelek Narodne in univerzitetne knjižnice.

30 O Jelki Todorović nismo našli zanesljivih podatkov, morda gre za Jeleno Todorović Ristić (1884-1953), hčerko Jelene Todorović in srbskega ministra Velimirja Todorovića, ki je obiskovala Dekliški zavod na Dunaju.

31 Dobroslava Đorđević (1884-1964) bila prijateljica Dimitrija Tucovića, saj so se ohranila njena pisma, iz katerih je razvidno, da sta si bila blizu (gl. Tucović 1974). V Beograd je prišla leta 1903 na študij filozofije, ki ga je tudi končala. Izhajala je iz izobražene družine. S Tucovićem se je spoznala na univerzi, pisala je feljtone za Radničke novine in Borbo, ki jih je on urejal. Ko je končala študij, je postala ravnateljica dekliške šole v Bitoli (glej Laketić 1974).

32 Pismo Jelke Todorović Zofki Kveder, 3. december 1925. Zapuščina Zofke Kveder, Ms 1113, Rokopisni oddelek Narodne in univerzitetne knjižnice To pismo je transkribirala dr. Snežana Kalinić.
} 
tudi iz recenzije Zofke Kveder o knjigi Milice Janković, kjer je zapisala: »Neobično volim Milicu Janković. Njezine su knjige »za uteho«. Čitam ih, da mi se odmori duša, da mi srce osvetlitračak blagosti i dobrote ljudske. /.../ Milica Janković je uvek i svukde iskrena, ona se odlikuje lepom, jednostavnom in nemaskiranom iskrenošću, koja je u srpskoj literaturi vrlo česta, a u našim stranama dosta redka, jer ne nailazi na poštovanje« (Kveder 1923, 217-218). Glede na takšno naklonjenost pisateljičinim knjigam ni presenetljivo, da je odlomek iz njenega dela Ispovesti (1913) vključila v svoj Almanah jugoslavenskih žena (1921), v katerem je objavila seveda tudi besedila Srbkinj, najbolj ugledne med njimi so bile Isidora Sekulić, Jovanka Hrvaćanin in Dora Pfanova.

Medtem ko so pisma Zofke Kveder navedenim srbskim prijateljicam izgubljena, se je ohranilo nekaj njenih pisem pisateljici, pesnici in prevajalki Jovanki Hrvaćanin (1899-1987). ${ }^{33}$ V njih se opravičuje za zapozneli odziv na njena pisma in pesmi, ki ji jih je J. Hrvaćanin poslala za objavo v Ženskem svijetu.Zaupala ji je, kako je izčrpana od skrbi za družino, družabnih obveznosti in poti v Maribor in Varaždin. Pisala ji je tudi o tem, kako je jezna na čitalnice, saj zaradi njih nima veliko naročnikov. Svoj zapozneli odgovor je opravičevala tudi z ogromno količino dela, saj je nekaj tednov na dan delala dvanajst do šestnajst ur. V zadnjem ohranjenem pismu jo je prosila za prispevke za Almanah jugoslavenskih žena in ji zaželela »mnogo lijepe, čiste i trajne sreće«. ${ }^{34}$ Ohranilo pa se je tudi nekaj pisem Jovanke Hrvaćanin, iz katerih je razvidno, da je pisateljico spoštovala. Zofka Kveder pa ji je ob srečanju v Zagrebu, 17. julija 1919, v spominsko knjigo zapisala: »Ostanite poeta, sve drugo - i studij $\mathrm{i}$ ispiti i mudrost koja se vadi iz tudjih knjiga, ostavit če vas gladnom i žednom. Volim Vas, pa želim, da mi još mnogo godina ovako dolazite u kuću na kratak, srdačan, intiman razgovor. Kada odlazite, ja ostajem manje sama nego obično. Vaša Zofka«. ${ }^{35}$

Pregled revije Ženski svijet, ki je bila leta 1919 preimenovana v Jugoslavensko ženo, prav tako potrdi tesne zveze med srbskimi avtoricami in Zofko Kveder, saj so bile stalne sodelavke časopisa »Dora Pfanova, Jovanka Hrvaćanin, Iva Rod, Katarina Bogdanović, Zorka Janković Velikovecka, Darinka Odović, Josipa Radošević, Mira Velikovecka, a Atanasijević, Vera Nažinić, Ljubica Milošević, Jela Ostojić i brojne druge autorke« (Svirčev 2012).

\footnotetext{
${ }^{33}$ Biljana Skopljak in Zorana Đukić, raziskovalki na projektu Knjiženstvo, sta odkrili štiri pisma, ki so iz obdobja med letoma 1918 in 1920. Eno izmed njih ima priloženo tudi besedilo Zofke Kveder, ki je izšlo ob prvi številki Ženskega svijeta. O Jovanki Hrvaćanin gl. tudi Ahmetagić 2012.

${ }^{34}$ Pismo Zofke Kveder Jovanki Hrvaćanin, 4. oktober 1920.

${ }^{35}$ Zapis u spomenaru Jovanke Hrvačanin, Ms 1432, 1.10.3. pisma.
} 


\section{Nekrologi}

Ob smrti Zofke Kveder je izšlo v srbskih časopisih nekaj krajših notic (Vittoreli 2008) in trije daljši nekrologi. Najobsežnejšega je napisala pisateljica, literarna zgodovinarka in prijateljica Zofke Kveder Zdenka Marković (1884-1974) za revijo Srpski književni glasnik. Njen zapis je osebno pisanje, ki se poglablja v pisateljičino osebnost in ugotavlja, ali je njeno življenje povezano s položajem ženske $v$ družbi in ali je pisateljičin značaj bil takšen, da jo je pripeljal do tragičnega konca. Ni hotela podati prikaza njenega dela, saj je bilo to še preveč blizu, da bi lahko o njem neobremenjeno pisala, temveč je hotela samo ujeti njeno še toplo dušo, točne konture njene osebnosti. Za Zdenko Marković je bila Zofka Kveder »jedna od najumnijih, najnesretnijih žena među nama«, njeno življenje in smrt sta največja »tragika žene što znam, bar najveća od zabilježenih i poznatih (tko da izdvoji sve one nepribelježene i nezapažene!), tragika probuđene, inteligentne, talentirane žena na našemu jugu, koja svojom težinom i sumornosti podsjeća samo još na tragiku svetske spisateljice Viktorije Benediktson« (Marković 1926, 608-609). V njeni osebnosti prepoznava dvojnost: veselje do življenja in nagnjenje k tesnobi, črnogledosti, v njenem življenju in delu so se prepletale črne in bele niti. Ko se je spominja, piše, da je bila svet zase, temperamentna, močna, zdrava duša, prava planinska narava, znala se je smejati s tistim vedrim, odprtim smehom, ko oči sijejo in se bleščijo, znala je uživati v lepoti sveta. A v njej je bila tudi globoko zakoreninjena tragika. Zdenka Marković izpostavi tudi njeno delovnost in zbiranje snovi za dela na vsakem koraku ter globok socialni čut: skrbela je za šolske otroke na periferiji mesta, služabnice, delavke. Ugotavlja tudi, da se nihče ni tako dal v svoja dela kot ona. Zaključek nekrologa je oseben in poetičen: Zofka Kveder je umrla in pri tem spoznala lepoto smrti in bolečine, kot je nekoč spoznala lepoto življenja in mladosti. Temno $\mathrm{v}$ njej je premagalo svetlo.

Minka Govekar je za »sestre Srpkinje« prav tako napisala spominski Članek in ga objavila v reviji Žena i svet. V njem je pregledno predstavila življenje in delo Zofke Kveder ter izpostavila njeno jugoslovanstvo: »Srpkinje će naročito interesirati, da je Zofka baš zbog svoje idealne i goruće težnje za što tešnje ujedinjenje zbog odlučnog naglašavanja jugoslovenske ideje mnogo patila za vreme rata i posle rata. Zbog otkritog »srbofilstva« su je hrvatski separatistički listovi nečovečanski napadali, ismevali i karikirali. Ali ipak nisu kritikovali njena literarna dela, već su je nemilostno sramotili kao ženu, mater i suprugu« (Govekar 1927, 8). Kot opozarja Žarka Svirčev je bila revija Jugoslavenska žena razumljena tudi kot časopis, ki je ustvaril »lepu vezu između Srpkinja, Hrvatica i Slovenki« (Govekar 1927, 8).

V Učitelju je nekrolog objavila Ida Runjanin in v njem predstavila pisateljičino življenje in delo, ki jima je dodala zelo tenkočuten spo- 
min na pisateljico: »Njezin entuzijazam k stvaranju velikih, plemenitih dela - njezina požrtvovnost. Ljubaznost, iskrenost, otvorenost silno su privlačile, i osećala sam, kako me njesine ubedljive rei, priče podižu nad ovu dolinu suza, punu nevolja, jada, zlobe ljudske u visine kroz beličaste oblake letnjeg predvečerja, ka zvezdama - ka nirvani« (Runjanin 1926, 476).

\section{Kasnejša recepcija Zofke Kveder v Srbiji}

Zanimiva oblika recepcije Zofke Kveder v srbskem kulturnem prostoru po njeni smrti je roman pisateljice, filozofinje in feministke Julke Chlapec Djordjević (1882-1969) Jedno dopisivanje. Fragmenti romana (1932), o katerem piše Alenka Jensterle Doležal, da je njegovo genezo inspiriralo tudi življenje Zofke Kveder. Glavni ženski lik, Marija Proharková, živi v Pragi: je bogata in razvajena Srbkinja, vzgojena je bila na Dunaju in ima tri otroke. O Zofki Kveder piše razpravo, vendar njenega imena ne omeni, skrije jo za inicijalke Z. K. Izhodišče romana je njena prošnja slovenskemu znancu, zdravniku dr. Otonu Šrepanu, ki je Z. K. poznal, da ji posreduje podatke o njej: »Pišem studiju o nedavnoj umrloj spisateljici Z. K., koju, nažalost, nisma lično poznavala, ali sam je voljela i cenila. Sećam se da ste studirali u Pragu u isto vreme kad i ona, i da ste bili s njom u velikom prijateljstvu, te bih Vam bila zahvalna da mi javite bliže podatke njenog života. Koja predavanja je posećivala? Da li se bavila u ono doba već žurnalistikom? Kada se upoznala sa K.? S kime se naročito družila? Kada je došla u Prag?« (Chlapec Đorđević 2018,112). Dopisovanje med Šerpanom in Proharkovo odkrije duhovne sorodnosti, ki vzbudijo željo po ponovnem srečanju, iz katerega sledi ljubezensko razmerje.

V zapuščini Erne Muser se je ohranil rokopis Eleonore Kernc, ki je opravila razgovor z Minko Govekar, ki je menila, da se za začetnicami skriva Zofka Kveder: »Njena pisma Etb. in Antonu Kristanu je dr. Žerovnik ${ }^{36}$ izposloval pri družini Antona Kristana za go. dr. Hlapec Đorđević, ki je spisala knjigo, v kateri igra glavno vlogo Zofka«. ${ }^{37}$ Alenka Jensterle Doležal je ob primerjavi Hanke in Jednega dopisivanja za roman Julke Chlapec Đordjević ugotovila: »V stilizaciji postav in zgodbe se mešajo tako avtobiografski elementi kot motivi iz Hanke (sama epistolarna forma romana, odprta kompozicija, fragmentarnost zapiskov, podob-

\footnotetext{
${ }^{36}$ Najverjetneje gre za dr. Antona Žerovnika (1881-1960), ki je študiral v Pragi, ko je tam živela Zofka Kveder. O njem smo našli le podatek, da je bil vabljen na večer, ki so ga organizirali praški študenti v ljubljanskem Narodnem domu 12. septembra 1900 , na katerem naj bi razpravljali o nacionalnem »jugoslovanskem« vprašanju (gl. Gantar Godina 1986, 301, ttp://www.zgodovinskicasopis.si/_pdf/Digital-archive/ZC_1986_3. pdf)).

37 Zapuščina Erne Muser, zbirka Eleonora Kernc, Rokopisni oddelek Narodne in univerzitetne knjižnice Ljubljana, Ms 1432.
} 
nost pa najdemo tudi v motivih: nesrečna zakonska zveza s tujcem, menjava različnih kultur, avstroogrsko ozadje, feministična pozicija glavne junakinje, navezava idealne korespondenčne zveze z moškim - intelektualcem ...)« (Jensterle Doležal 2014, 149). Raziskovalka na istem mestu še dodaja, da je Julka Chlapec Đordjević v dvajsetih letih nekaj časa raziskovala tudi življenje in delo Zofke Kveder, napisala pomemben članek o njej in recenzirala njene hrvaške knjige $v$ češkem in hrvaškem prostoru. Članek, ki ga omenja A. Jensterle Doležal, je obsežna študija o Zofki Kveder v češkem kulturnem prostoru (Из прашких дана Зофке Кведерове). ${ }^{38}$ V zaključku te študije je J. Chlapec Đordjević lucidno ugotovila, da moramo na pisateljičin opus pogledati s širše perspektive: »U redu naših kulturnih radnica, Zofka stoji usamljena. Njena ogromna i svestrana radnost, boemstvom protkana emancipovanost, uz vrlo razvijen osećajni život, kao i izvesne crte lične sudbine, sećaju nas na pionira našeg feminističkog pokreta, na omladinku Dragu Dejanović. Značaj Zofke Kvederove ne leži toliko na polju književnosti ili feminizma koliko u njenoj ličnosti i celokupnosti njenoga rada« (Chlapec Djordjević 1928, 130). Kakor navaja Ž. Svirčev (2012), je leta 1932 spominski zapis o pisateljici izšel tudi v reviji Jugoslovenska žena.

Med novejšimi raziskavami Zofke Kveder v srbski literarni vedi je pozornosti vredna raziskava Žarke Svirčev, ki je analizirala časopis Jugoslavenska žena in opozorila na povezanost med tedanjimi revijami iz srbskega prostora in revijo, ki jo je urejala Zofka Kveder: »Naime, tekstovi su objavljeni u Ženskom pokretu, Ženi i svetu, Ženskom svetu i Jugoslavenskoj ženi. Svi časopisi imali su potrebu da odaju poštu Zofki Kveder i, iako sažeti, mesta su našli prevashodno za njenu Jugoslavensku ženu. Dakle, ideološki drugačije orijentisani časopisi svoju prethodnicu vide u časopisu Zofke Kveder« (Svirčev 2012). V reviji so bili objavljeni, kot opozarja Ž. Svirčev, tudi portretni članki o srbskih pisateljicah: Milici Stojadinović Srpkinji, Jeleni Dimitrijević, Isidori Sekulić in Milici Janković, za katere je značilno, da so bili hibridno koncipirani in so prinašali »biografije žena, akcentujući intelektualne profile i njihovu ideološku opredeljenost, odlučnost i borbenost u savlađivanju društvenih prepreka, kao i interpretaciju njihovih književnih tekstova stavljajući težište na emancipatorski diskurs koji ih prožima. Važnost i značaj javnog angažmana, moć pisane reči i podsticajnost ličnog primera u emancipatorskim procesima lajt-motivi su ženskih portreta u kojima su predstavljene spisateljice. Mozaički ukršteni portreti prethodnica formiraju bogatu mrežu ženskog autorstva čiji je cilj uspostavljanje kontinuiteta ženske stvaralačke tradicije i svojevrsna podrška/ogledalo savremenicama« (Svirčev 2012).

38 O povezavah med romanoma Hanka in Jedno dopisivanje. Fragmenti romana. gl. tudi Jensterle Doležal 2016. 


\section{Zaključek}

Raziskava stikov Zofke Kveder s srbskim kulturnim prostorom je pokazala, da je pisateljica gojila literarne in prijateljske stike s Srbkinjami in Srbi. Njeno delo je bilo sprejeto kot pomemben del južnoslovanske kulture in literature. Iz pisem, ki jih je dobivala iz Srbije, lahko razberemo, da je njena podoba številnim ženskam, ki so jo poznale osebno ali le iz njenih del, pomenila navdih za lastna emancipacijska dejanja. Današnji pogled na Zofko Kveder razkriva, da med pomembne zasluge na literarnem polju sodi tudi njeno kulturno posredništvo. S svojim delovanjem je obogatila prostore, $v$ katere je vstopala, a hkrati je $z$ odprtostjo svojega duha iz njih srkala najbolj žlahtne kulturne dobrine in človeške veličine osebnosti, s katerimi se je srečevala. Sodelovanje $\mathrm{z}$ intelektualci in intelektualkami iz srbskega prostora je nedvomno obogatilo njeno življenje in delo.

\section{Literatura}

Ahmetagić, Jasmina. 2012. Pisanje kao čežnja za sagovornikom. Književno delo Jovanke Hrvaćanin. Knjiženstvo 2(2). http://www.knjizenstvo.rs/sr-lat/ casopisi/2012/zenska-knjizevnost-i-kultura/pisanje-kao-ceznja-zasagovornikom-knjizevno-delo-jovanke-hrvacanin

Badurina, Natka. 2009. Nezakonite kćeri Ilirije. Hrvatska književnost i ideologija u 19. i 20. stotjeću. Zagreb: Center za ženske studije.

Barbarič, Štefan. 1980. Milan Marjanović kot slovensko-hrvatski literarni posrednik. Slavistična revija 28 (4): 457-474.

Chlapec Đorđević, Julka. 1928. Iz praških dana Zofke Kvederove. Letopis Matice Srpske 2(1): 124-131.

Chlapec Đorđević, Julka. 2018. Jedno dopisivanje. Fragmenti jednog romana. Beograd: Laguna.

Dimitrova, Ljudmila Malinova. 2012. »Zofka Kveder in Petko Todorov - srečanje in razhajanje slovenskega in bolgarskega modernizma $v$ dramatiki«. V Slovenska dramatika, ur. Mateja Pezdirc Bartol, 175-180. Ljubljana: Znanstvena založba Filozofske fakultete.

Govekar, Minka. 1927. Zofka Kveder Demetrović. Žena i svet 21. januar.

Jensterle-Doležal, Alenka. 2014. Avtor, tekst, kontekst, komunikacija. Poglavja iz slovenske moderne. Maribor: Mednarodna založba Oddelka za slovanske jezike in književnosti - Filozofska fakulteta.

Jensterle-Doležal, Alenka. 2016. Genealogija u južnoslovenskom romanu 20. veka: Zofka Kveder i Julka Hlapec-Đorđević. Knjiženstvo 6(6). http:// www.knjizenstvo.rs/sr-lat/casopisi/2016/zenska-knjizevnost-i-kultura/ genealogija-u-juznoslovenskom-romanu-20-veka-zofka-kveder-ijulka-hlapec-djordjevic 
Kveder, Zofka. 1913. Jedanaest novela. Zbirka Savremeni hrvatski pisci. Knj. 29. Zagreb: Društvo hrvatskih književnika.

Kveder, Zofka. 1917. Hanka. Zagreb: Hrvatski štamparski zavod.

Kveder, Zofka. 1917. Vojnici, ranjenici, čuvajte pisma svojih majka i žena. Beogradske novine 5. september.

Kveder, Zofka. 1918. O prošlosti, sadašnjosti, budučnosti. Jugoslavenska žena 2 (12): 473-486.

Kveder,Zofka.1923. Milica Janković: Čekanje.Jugoslavenska njiva l7 (5): 217-218.

Kveder, Zofka. 2005. Zbrano delo. Knjiga 1. Maribor: Litera.

Kveder, Zofka. 2010. Zbrano delo. Knjiga 2. Ljubljana: Založba ZRC, ZRC SAZU.

Kveder, Zofka. 2013. Zbrano delo. Knjiga 3. Ljubljana: Založba ZRC, ZRC SAZU.

Kveder, Zofka. 2016. Zbrano delo. Knjiga 4. Ljubljana: Založba ZRC, ZRC SAZU.

Kveder, Zofka. 2018. Zbrano delo. Ljubljana: Založba ZRC, ZRC SAZU.

Laketić, Milana. 1974. Dobrosavine prijateljice. Duga 16. 11.

Marjanović, Milan, 1902. Iz novije slovenske literature. I. Cankar i Z. Kvedrova. Kolo 2(5): 353-358.

Marković, Zdenka. 1926. Zofka Kveder. Srpski književni glasnik 25 (19): 608-613.

Mihurko Poniž, Katja. 2019. Bolgarsko-slovensko prijateljstvo v življenju in delih Zofke Kveder = The Bulgarian-Slovenian friendship in the life and works of Zofka Kveder.V B"lgarija - Makedonija-Slovenija : meždukulturni dialozi $v$ XXI vek : recenzirana kolektivna naučna monografija = Bugarija - Makedonija - Slovenija : megukulturni dijalozi vo XXI vek = Bolgarija Makedonija - Slovenija : medkulturni dialogi v XXI stoletju, ur. Namita Subiotto in Ljudmil Dimitrov, 205-216. Sofija: Nacionalno izdatelstvo za obrazovanie i nauka »Az-buki«.

Runjanin, Ida, 1926-1927. Zofka Kveder Demetrović. Učitelj 7(6): 476-478.

Vittorelli, Natascha. 2008. »ejí život, její smrt. Život Zofky Kveder po její smrti«. V Zofka Kvedrová, (1878-1926) : recepce její tvorby ve 21. století, ur. Jasna Honzak Jahič in Alenka Jensterle-Doležalová, 221-232. Praga: Národní knihovna ČR, Slovanská knihovna.

Svirčev, Žarka. 2012.Jugoslavenska žena - forum moderne spisateljice. Knjiženstvo 5(5). http://www.knjizenstvo.rs/sr-lat/casopisi/2015/zenska-knjizevnost-i-kultura/ jugoslavenska-zena-forum-moderne-spisateljice

Tucović, Dimitrije. 1974. Преписка. Titovo Užice : »Dimitrije Tucović«.

Ženskinje kod Slovenaca. 1906. Pravda 11. junij. http://www.digitalna.nb.rs/wb/ NBS/novine/pravda/1906/07/11\#page/0/mode/1up 
Katja Mihurko Poniž

Univerzitet u Novoj Gorici

Fakultet za humanistiku

Slovenija

\section{VEZE ZOFKE KVEDER SA SRPSKIM KULTURNIM PROSTOROM}

Članak predstavlja različite oblike kulturnih kontakata Zofke Kveder sa srpskim intelektualcima. U prvom delu obrađuju se objave njenih književnih tekstova na srpskom kulturnom prostoru i reakcija kritičara. U drugom delu, polazeći od korespondencije Zofke Kveder, rekonstruiše se odnos između nje i Dimitrija Tucovića, koji ju je podstakao da putuje u Srbiju, kuda se ona zaista i uputila neposredno pre Prvog svetskog rata. Taj put je u nastavku članka takođe detaljno opisan. Pažnja se usmerava i na autorkina dela, pre svega na likove Srba i Srpkinja koji se pojavljuju već u njenim ranijim književnim tekstovima. U romanu Hanka, u liku Kazimira Stašinjskog (Staszyńskog), ona prikazuje muškarca sa mnogim karakteristikama Dimitrija Tucovića. Kao žena kraljevskog zamenika za Hrvatsku i Slavoniju, posle rata češće posećuje Beograd i razvija mnoga poznanstva, koja u nastavku ovog članka predstavljamo kroz njenu korespondenciju. Većina pisama upućenih srpskim prijateljicama danas je izgubljena, dok na osnovu onih koja su se sačuvala možemo zamisliti mrežu prepiske Zofke Kveder na Balkanu, pri čemu iz njih, takođe, možemo da razaberemo kako su se na srpskom prostoru sa Zofkom povezivale, pre svega, autorke i feministkinje. U članku zatim slede reakcije na rad i lik Zofke Kveder nakon njene smrti - kako u nekrolozima tako i u književno-naučnim studijama o njoj. Njen rad je prihvaćen kao važan deo južnoslovenske kulture i književnosti.

Ključne reči: Zofka Kveder, srpsko-slovenački književni kontakti, Dimitrije Tucović, Milica Đurič Topalović, Julka Hlapec Đordjević, Jelena J. Dimitrijević

Katja Mihurko Poniž

University of Nova Gorica

School of Humanities

Slovenia

\section{ZOFKA KVEDER'S LINKS WITH THE SERBIAN CULTURAL SPACE}

The paper presents the various forms of Zofka Kveder's cultural contacts with Serbian intellectuals. The first section of the paper deals with the emergence of her literary texts in the Serbian cultural space and the reactions of critics. Based on the correspondence of Zofka Kveder, the second section seeks to reconstruct her relationship with Dimitrije Tucović, who encouraged her to travel to Serbia, which she did immediately before World War I. The paper describes the trip in great 
detail. Attention is drawn to Kveder's writings and primarily Serbian men and women appearing as characters already in her early literary works. In her novel Hanka, through the character Kazimir Staszyński she portrayed a man that shared many personal traits with Dimitrije Tucović. As the wife of the royal deputy in Croatia and Slavonia, she visited Belgrade more often after the war and she developed many acquaintances, which are presented in the paper through her correspondence. Although the greatest part of the letters sent to her Serbian friends are lost, the surviving ones make it possible to get an idea of Zofka Kveder's correspondence network in the Balkans. They also suggest that her contacts in the Serbian cultural space primarily included women writers and feminists. The paper also discusses the reactions to her and her work after her death - both in obituaries and in scholarly studies. Her work has been considered an important segment of South Slavic culture and literature.

Keywords: Zofka Kveder, literary contacts between Serbia and Slovenia, Dimitrije Tucović, Milica Đurič Topalović, Julka Chlapec Đorđević, Jelena J. Dimitrijević 